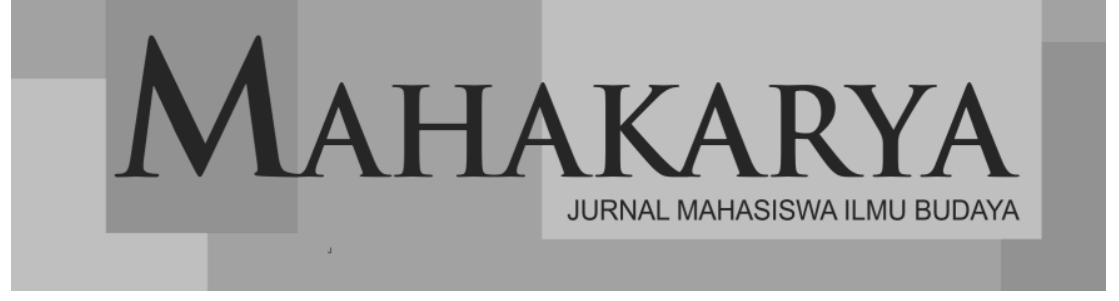

Volume 1 Nomor 1 - Maret 2020

\title{
KOHESI LEKSIKAL WACANA BERITA PELANTIKAN PRESIDEN DI MEDIA DARING TEMPO.CO
}

\author{
Fadila Sukma Wijaya \\ fadilasukma75@gmail.com \\ Program Studi Tadris Bahasa Indonesia IAIN Surakarta
}

\begin{abstract}
The study aims to describe and explain the results of the lexical cohesion analysis contained in Tempo.co online media related to reporting the presidential inauguration of the October 2019 edition. The method used is in this research is a qualitative descriptive method with 3 stages: (1) searching for data, (2) analyzing data, and (3) presenting data. Research data in the form of news uploads inauguration of the president on the daring media Tempo.co in October 2019. From the results of the study there were six types of lexical cohesion, where the type of repetition or repetition of lexical cohesion is most commonly found.
\end{abstract}

Keywords: lexical cohesion, online media news, Tempo.co

\section{Pendahuluan}

Dalam berkomunikasi manusia membutuhkan bahasa, untuk mengetahui maksud dari yang akan dibicarakan. Semua orang menyadari, bahwa interaksi dan segala macam kegiatan dalam masyarakat akan lumpuh tanpa bahasa. Menurut (Keraf 1980, 1) bahasa merupakan simbol dan alat komunikasi masyarakat untuk berinteraksi satu sama lainnya.

Sebagai alat komunikasi, bahasa tidak dirinci dalam bentuk bunyi, frasa ataupun kalimat secara terpisah, tetapi dipakai dalam bentuk yang saling berkaitan. Adanya kalimat pertama akan menimbulkan kalimat kedua, kalimat kedua aka nada kalimat ketiga dan seterusnya seperti itu. Oleh karena itu, rentetan kalimat yang saling berkaitan akan menghubungkan proposisi yang lain dan membentuk kesatuan yang disebut tuturan atau wacana.

Salah satu media komunikasi dengan berbagai wacana yaitu surat kabar. Surat kabar merupakan suatu bentuk komunikasi nonverbal. Seeiring perkembangan zaman, suart kabar dalam penyampaiannya memiliki dua bentuk yaitu media cetak dan media daring (dalam jaringan/online). Seperti yang akan dibahas dalam penelitian ini, surat kabar yang yang dipakai adalah media daring Tempo.co. selain Tempo.co masih banyak lagi yang lainnya seperti Tribunnews.com, Detik.com, Suara.com dan masih banyak lagi.

Media daring Tempo.co merupakan salah satu surat kabar yang terdapat dalam internet. Surat kabar ini, selalu memberitakan berita terkini dari dalam negeri maupun dari mancanegara. Rubrik dalam Tempo,co ada banyak seperti rubrik nasional, bisnis, metro, dunia, bola, sport, cantic, otomotif, kolom, seleb, travel dan masih banyak lagi.

Pemberitan yang sedang hangat pada bulan Oktober 2019 pada Tempo.co adalah mengenai pelantikan presiden dan wakil presiden periode 2019-2024. Peneliti tertarik ingin menganalisis mengenai hal tersebut. Maka penelitian yang akan penelitikaji ini adalah, penelitian yang bertujuan untuk memberikan informasi mengenai jenis leksikal pada surat kabar daring yaitu Tempo.co. Dan juga untuk menyempurnakan penelitian sebelumnya. Bedasarkan latar belakang di atas, permasalahan dalam penelitian ini adalah bagaimanakah 
bentuk kohesi leksikal dalam pemberitaan pelantikan presiden pada media daring Tempo.co edisi Oktober 2019.

Penelitian terkait kohesi leksikal pada wacana pernah dilakukan oleh Utami (2016) dalam artikel jurnalnya yang berjudul Analisis Kohesi Leksikal Rubrik Pembaca Menulis Surat Kabar TanjungPinang Pos Edisi Februari 2016. Dari penelitian tersebut, banyak ditemukan kohesi leksikal repetisi atau pengulangansebanyak 122 data. Persamaan pada penelitian tersebut dengan penelitian ini yaitu sama-sama menganalisis kohesi leksikal pada surat kabar. Perbedaannya terletak pada bentuk penyampaian surat kabar dan nama surat kabarnya. Pada penelitian terdahulu pada surat kabar yang berbentuk koran cetak dengan nama Tanjung Pinang Pos, sedangkan pada penelitian ini surat kabar dari unggahan media Daring dengan nama Tempo.co

Selain itu, penelitian serupa juga pernah diteliti oleh Pernando \& Rahima (2016) dalam artikel jurnalnya yang berjudul Analisis Kohesi Leksikal dalam Majalah Patriotik LPM Universitas Batanghari Edisi XVI Juli-September Tahun 2016. Dari penelitian tersebut, ditemukan jenis kohesi leksikal repetisi atau pengulangan. Persamaan penelitian tersebut dengan penelitian ini adalah sama-sama menganalisis kohesi leksikal. Perbedaannya ada pada jenis objek yang dianalisis, jika penelitian tersebut menganalisis majalah, makan peneletiain ini menganalisis surat kabar media daring Tempo.co.

Selanjutnya penelitian yang dilakukan oleh Tonang dalam artikel jurnalnya yang berjudul Kohesi Leksikal pada Surat Kabar Sulteng Raya (2018). Adapun hasil penelitian dari 49 data ditemukan dua jenis kohesi leksikal yaitu 42 repitisi dan 7 kolokasi. Berarti dalam penelitian ini, penulis hanya memfokuskan pada repitisi dan kolokasi saja pada suatu wacana. Persamaan peneliatian tersebut dengan penelitian ini yaitu sama-sama menganalisis kohesi leksikal pada surat kabar. Perbedannya yaitu nama surat kabar dan bentuk penyampaiannya, penelitian tersebut menganalisis surat kabar Sulteng Raya dengan media cetak sedangkan penelitian ini, menganalisis surat kabar dari media daring Tempo.co. Penelitian tersebut, juga hanya focus pada dua jenis kohesi leksikal yaitu repetisi dan kolokasi, sedangkan penelitian ini menguraikan enam jenis kohesi leksikal.

Hartono $(2012,12)$ menyatakan bahwa wacana adalah kebahasaan yang memiliki unsur terlengkap, secara lisan maupun tulis yang membentuk suatu kalimat padu, baik dalam pengertian maupun dalam fonetisnya. Wacana yang baik harus memperhatikan hubungan antarkalimat, agar antarkalimat dapat berkaitan dan menjadi runtut. Tarigan $(2009,26)$ juga mengungkapkan bahwa wacana adalah satuan bahasa yang paling lengkap, lebih tinggi, dari klausa dan kalimat, memiliki kohesi dan koherensi yang baik, mempunyai awalan dan akhiran yang jelas, berkaitan satu sama lain, dan dapat disampikan secara lisan maupun tulis.

Suatu wacana harus memiliki hubungan yang saling berkaitan dan runtut dalam setiap kalimatnya. Untuk itu perlu memahami struktur dari sebuah wacana. Selain itu juga, keutuhan wacana juga mengandung aspek-aspek yang terpadu dan menyatu. Untuk menyelaraskan antar kalimat agar saling berkaitan dan menjaga keutuhan struktur dalam wacana, maka wacana memiliki dua unsur yaitu unsur kohesi dan koherensi. Kohesi merupakan aspek formal bahasa dalam wacana (hubungan yang tampak pada bentuk). Kohesi merupakan wadah kalimat-kalimat yang disusun secara padu dan padat untuk menghasilkan tuturan (Tarigan 2009, 93). Dengan demikian, kohesi berfungsi sebagai penhubung antar bagian di dalam wacana sehingga wacana yang bersangkutan utuh sebagai satu kesatuan makna.

Kohesi terbagi atas dua macam yaitu kohesi gramatikal dan kohesi leksikal. Menurut Yuwono (dalam Kushartanti 2005, 96) kohesi gramatikal adalah kalimat-kalimat antar unsur yang berhubungan digunakan dengan tata bahasa. Kohesi gramatikal seperti referensi (pengacuan), substitusi (pengganti), elipsis (pelesapan), dan konjungsi (kata hubung). Sedangkan pendapat lain kohesi leksikal menurut Kushartanti $(2005,96)$ adalah hubungan 
antar unsur wacana yang dapat menghubungkan kalimat dengan leksikal atau kata. Sejalan dengan yang dikemukakan oleh Sumarlam $(2010,35)$ menyatakan bahwa jenis-jenis kohesi leksikal yaitu, kolokasi, hiponimi, ekuivalensi, sinonimi, antonomi, dan repitisi.

\section{Metode Penelitian}

Penelitian ini menggunakan metode deskriptif kualitatif, yaitu penelitian yang di deskripsikan secara rinci dan di tuliskan secara jelas dan runtut sehinnga menghasilkan dan mendapatkan data secara jelas (Nugrahani 2010, 116). Penelitian ini terdapat dalam unggahan surat kabar daring Tempo.co yaitu mengenai pemberitaan pelantikan Presiden dan Wakil Presiden periode 2019-2024 pada bulan Oktober 2019. Data dalam penelitian ini adalah kalimta-kalimat atau kata yang termasuk dalam kohesi leksikal.

Teknik yang digunakan dalam penelitian ini adalah teknik pengkajian dokumen atau arsip. Analisis dokumen, dapat dengan mudah mencari data dengan melihat objek yang diteliti dan juga dapat mengarsipkan dengan jelas tindak verbal dalam suatu uajaran (Muhadjir 1996, 49 dalam Nugrahani 2010, 102). Dalam teknik ini, penulis menggunakan 3 tahapan, yaitu: (1) mencari data, (2) analisis data, dan (3) penyajian data.

Pencarian data dilakukan dengan cara melihat dan membaca surat kabar daring yaituTempo.co. Selain itu juga, mencari data dokumen lainnya berupa artikel-artikel dan bahan-bahan lainnya yang dapat digunakan untuk penelitian ini. Setelah data sudah tersedia, maka tahap kedua yaitu menganalisis data. Tahap ini, adalah tahap mentranskip data dimana semua data yang dibutuhkan dituliskan terlebih dahulu. Data di ambil secara acak mulsi tanggal 01 hingga 26 bulan Oktober 2019. Setelah itu, data dipilih dan dikelompokkan sesuai kebutuhan peneliti, diantaranya kolokasi, hiponimi, sinonimi, ekuivalansi (kesepadanan), antonimi, dan repitisi (pengulangan). Teknik terakhir yang digunakan dalam penelitian ini adalah dengan mengelompokkan atau mengkalsifikasi data sesuai kebutuhan penelitian diantaranya kolokasi, hiponimi, sinonimi, ekuivalansi (kesepadanan), antonimi, dan repetisi (pengulangan).

\section{Pembahasan}

Dalam media daring Tempo.co yang memberitakan mengenai Pelantikan Presiden Oktober 2019, ditemukan pada unggahan Oktober 2019, sebanyak 35 wacana. Berikut telah didapatkan berbagai macam kohesi leksikal yaitu, kolokasi, hiponimi, ekuivalensi (kesepadanan), sinonimi, antonimi, dan repetisi (pengulangan) berikut adalah pembahasan mengenai penelitian dan data yang telah didapatkan.

\section{Kolokasi}

Menurut Sumarlam $(2010,44)$ kolokasi adalah pembentukan hubungan tertentu dengan menggunakan pilihan kata yang dapat digunakan secara berdampingan. Dari data yang di dapatkan, ditemukan kolokasi dalam pemberitaan pelantikan presiden di media daring Tempo.com. Di bawah ini merupakan contoh beberapa kalimat kolokasi, sebagai berikut.

(1) Kepala Bagian Penerangan Umum Divisi Humas Mabes Polri Komisaris Besar Asep Adi Saputra mengatakan, selain di Jakarta saja, pengamanan juga akan dilakukan di seluruh daerah. "Dua puluh tujuh ribu personel disiapkan tidak hanya dari Polri, tapi juga TNI, pemerintah daerah dan instansi terkait," kata Asep saat dikonfirmasi, Senin, 7 Oktober 2019.

Data (1) menunjukkan adanya kolokasi yang ditunjukkaan dalam kalimat Dua puluh tujuh ribu personel disiapkan tidak hanya dari Polri, tapi juga TNI, pemerintah daerah dan instansi terkait. Wacana tersebut membentuk kolokasi leksikal karena unsur-unsurnya termasuk personel yang akan mengamankan jalannya pelantikan pesiden dan wakil presiden periode 2019-2024. 
Fadila Sukma Wijaya

(2) Apalagi, menurut Prabowo, susunan Pimpinan MPR kali ini adalah yang terbaik."Mudahan-mudahan mereka bisa memenuhi harapan rakyat, harmoni, menjaga kerukunan, jangan oligarki, semua membela kepentingan rakyat. Selamat bekerja," ujar Prabowo.

Pada wacana di atas ditemukan adanya kolokasi pada kalimat "Mudahan-mudahan mereka bisa memenuhi harapan rakyat, harmoni, menjaga kerukunan, jangan oligarki, semua membela kepentingan rakyat. Selamat bekerja," ujar Prabowo. Dari kalimat tersebut terdapat unsur-unsur dalam harapan Prabowo untuk negara Indoesia yang akan dipimpin oleh Jokowi.

(3) Menurut Fadel, persiapan pelantikan juga difinalisasi hari ini bersama Presiden Joko Widodo atau Jokowi. Ia bersama pimpinan MPR lainnya datang ke Istana untuk membahas tiga hal bersama Jokowi, yakni mengenai waktu acara, agenda acara, dan materi sambutan yang akan disampaikan Jokowi sesudah pelantikan.

Data (3) terdapat kolokasi pada kalimat waktu acara, agenda acara, dan materi sambutan yang akan disampaikan Jokiwo sesudah pelantikan. Dalam kutipan tersebut merupakan serangkaian acara yang akan dilaksanakan dalam pelantikan presiden pada tanggal 20 Oktober 2019.

(4) Dari informasi yang diterima BIN sejumlah tamu kenegaraan, yaitu ada dua kepala negara, empat kepala pemerintahan, sembilan orang utusan khusus, dan 157 lebih duta besar yang diperkirakan akan hadir.

Data (4) terdapat adanya kolokasi pada kalimat sejumlah tamu kenegaraan, yaitu ada dua kepala negara, empat kepala pemerintahan, sembilan orang utusan khusus, dan 157 lebih duta besar yang diperkirakan akan hadir. Kata yan ditemukan masuk kedalam satu unsur yang sama yaitu, tamu dari jajaran keneharaan yang akan menghadiri pelantikan presiden dan wakil presiden pada tanggal 20 Oktober 2019.

(5) Sejumlah personel Brimob dan Paspampres juga bersiaga di dekat kendaraan tempur itu. Siang ini, pengamanan di gedung DPR/MPR sangat ketat. Di luar gedung DPR/MPR, pengamanan ketat juga diberlakukan. Area gedung DPR/MPR steril dari lalu lintas kendaraan mulai dari Hotel Mulia atau jalan mengarah ke pintu masuk DPR/MPR, Senayan hingga arah rel kereta api Palmerah.

Wacana di atas ditemukan adanya kolokasi pada kalimat Area gedung $D P R / M P R$ steril dari lalu lintas kendaraan mulai dari Hotel Mulia atau jalan mengarah ke pintu masuk DPR/MPR, Senayan hingga arah rel kereta api Palmerah. Kata yang ditemukan terasuk ke dalam satu unsur yang sama yaitu tempat yang diamankan sangat ketat dan di strerilkan demi keamanan pelantikan presiden dan wakil presiden periode 2019-2024.

Hiponimi

Hiponimi adalah satuan bahasa (kata, frasa, dan kalimat) yang maknanya dianggap bagian satuan lingual yang lain (Sumarlam, 2010: 45). Leksikal hiponimi adalah suatu kata yang terdapat dalam suatu golongan tertentu atau bisa dikatakan dalam satu bidang tertentu. Dalam wacana pemberitaan pelantikan presiden 2019 pada media daring Tempo.co ditemukan juga hiponimi. Di setiap data, pasti terdapat hiponimi yang digunakan dalam paragaraf-paragrafnya. Berikut contoh beberapa hiponimi yang telah didapatkan.

(6) Para pimpinan MPR telah mengirimkan undangan kepada sejumlah tokoh dan pejabat, termasuk presiden kelima RI Megawati Soekarnoputri, Ketua Umum Partai Gerindra Prabowo Subianto, mantan calon wakil presiden Sandiaga Uno dan Wakil Presiden terpilih Ma'ruf Amin. 
Data (6) hiponimi terdapat pada kutipan "tokoh dan pejabat, termasuk presiden kelima RI Megawati Soekarnoputri, Ketua Umum Partai Gerindra Prabowo Subianto, mantan calon wakil presiden Sandiaga Uno dan Wakil Presiden terpilih Ma'ruf Amin". Dari kutipan tersebut masuk kedalam satu persoalan mengeai tamu undanagan yang diundang oleh pimpinan MPR RI.

(7) Jika ditotal, jumlah mobil yang disiapkan untuk menyambut kehadiran para tamu negara pada pelantikan Presiden dan Wakil Presiden akhir pekan ini adalah Mercedes Benz tipe S450 sebanyak 11 unit, cadangan 1 unit, Mercedes Benz tipe E30o sebanyak 13 unit, Mercedes Benz E250 sebanyak 4 unit, Mercedes Benz tipe E20o sebanyak 10 unit, Toyota Alphard 18 unit, Toyota Camry 9, dan Toyota Fortuner sebanyak 27 unit.

Data (7) di atas dikatakan hiponimi, karena menyebutkan tipe-tipe mobil seperti pada kutipan "Mercedes Benz tipe S45O sebanyak 11 unit, cadangan 1 unit, Mercedes Benz tipe E3Oo sebanyak 13 unit, Mercedes Benz E25O sebanyak 4 unit, Mercedes Benz tipe E2OO sebanyak 10 unit, Toyota Alphard 18 unit, Toyota Camry 9, dan Toyota Fortuner sebanyak 27 unit." Mobil-mobil tersebut masuk ke dalam satu jenis unsur yaitu golongan kendaraan. Pada penatikan presiden, kendaraan mewah sudah disipakan, kendaraan itu adalah mobilmobil mewah dengan berbagai tipe.

(8) Untuk pengamanan ibu kota dalam pelantikan Presiden dan Wakil Presiden, Minggu, 20 Oktober 2019, pihak keamanan menempatkan sejumlah panser Anoa di beberapa sudut Ibu Kota Jakarta. Setidaknya sejak Jumat, 19 Oktober 2019, kendaraan taktis militer Anoa terlihat di sejumlah mal, di antaranya di Mal Taman Anggrek, Jakarta Barat, dan LTC Glodok, Jakarta Pusat.

Data (8) Hiponimi yang ditemukan pada kalimat "Mal Taman Anggrek, Jakarta Barat, dan LTC Glodok, Jakarta Pusat." Unsur yang ditemukan adalah dalam satu nama tempat yaitu mall. Tempat yang sebutkan berada di di satu daerah yaitu Jakarta Pusat. Pemakaian hiponimi disini berfungsi untuk menyebutkan tempat yang ditempatkan oleh panser anoa.

(9) Berdasarkan informasi yang dihimpun setidaknya Jokowi akan kedatangan 13 tamu negara. Mereka yang hadir ke Istana sebelum pelantikan antara lain Sultan Brunei Darussalam Hassanal Bolkiah, Perdana Menteri Australia Scott Morrison beserta istri, Perdana Menteri Republik Singapura, Y.M. Lee Hsien Loong beserta istri, Perdana Menteri Kamboja Hun Sen dan Raja Eswatini Mswati III beserta istri.

Pada wacana di atas, data (9) terdapat banyak nama-nama orang yang akan hadir dalam pelanikan presiden dan wakil presiden periode 2019-2024. Kalimat tersebut pada "Sultan Brunei Darussalam Hassanal Bolkiah, Perdana Menteri Australia Scott Morrison beserta istri, Perdana Menteri Republik Singapura, Y.M. Lee Hsien Loong beserta istri, Perdana Menteri Kamboja Hun Sen dan Raja Eswatini Mswati III beserta istri." Unsur yang terdapat wacana tersebut adalah nama-nama tamu negara. Berbagai nama tamu undangan dari berbagai negara menjadi tamu pelantikan presiden dan wakil presiden periode tahun 2019-2024.

(10) ... Ia berharap, kesuksesan dan kelancaran pelantikan Kepala Negara hari ini menjadi awal bagi pemerintah untuk memajukan Indonesia. "Sekali lagi, menarik saya kira Mas Bamsoet tampak santai, walaupun (acaranya) sempat molor tapi pembawaanya santai, banyak senyum, pantun, guyon juga," ujar Usep.

Data (10) Hiponimi dapat menggolongkan berbagai jenis atau bidang, asalkan masih dalam satu kelompok yang sama. Pada wacana di atas ditemukan hiponimi dalam satu jenis suasana yang dimiliki oleh orang. Kalimat tersebut yaitu "santai, banyak senyum, pantun, 
guyon juga”. Tergolong hiponimi karena, dari kalimat tersebut termasuk ke dalam jenis yang sama yaitu, menggambarkan suasan sesorang.

\section{Ekuivalensi}

Ekuivalensi (kesepadanan) adalah hubungan dari lingual yang satu dengan lingual lainnya dalam sebuah konteks. Ekuivalensi terjadi karena adanya proses afiksasi atau pembentukkan bentuk kata baru (Avianto, 2018: 28). Berikut ini adalah beberapa contoh ekuivalensi pada pemberitaan pelantikan presiden oktober 2019 dalam media daring Tempo.co.

(11) Pelantikan presiden dan wakil presiden sendiri akan digelar di Kompleks Parlemen. Presiden inkumben Joko Widodo dan Wakil Presiden terpilih Ma'ruf Amin akan dilantik pada 20 Oktober 2019.

Data (11) Ekuvalensi yang ditemukan pada wacana diatas adalah pelantikan dan dilantik. Kedua kata tersebut berasal dari kata dasar yaitu lantik. Satu kata yang ditambahkan dengan afiksasi pe-..-kan, dan di-. Perubahan menjadikan 2 bentuk yang sebanding.

(12) Sebanyak 27 ribu personel TNI-Polri akan dikerahkan untuk menjaga keamanan pelantikan presiden. Seluruh personel akan mengamankan tempat-tempat sentral di Jakarta. Pelantikan itu sendiri akan digelar di Kompleks DPR RI.

Dari data (12) wacana di atas ditemukan ekuivalensi dari kata keamanan dan mengamankan. Kedua kata tersebut berasal dari kata dasar aman. Edua kata tersebut sebanding karena wacana menuliskan tentang penjagaan di pelantikan presiden dan wakil presiden periode tahun 2019-2024. Walaupun artinya berbeda, keamanan berarti keadaan yang aman, sedangkan mengamankan yaitu tindakan yang dapat melindungi atau membuat aman, namun kedua kata tersebut sebanding dengan kalimat-kalimta yang ada dalam wacana.

(13) Jokowi memastikan bahwa demonstrasi juga dijamin konstitusi. Namun, jika ada larangan berdemo, ia meminta agar ditanyakan langsung kepada kepolisian. "Namanya demo dijamin konstitusi," ujar Jokowi.

Data (13) di atas ditemukan tiga kata yang termasuk ke dalam ekuivalensi yaitu demonstrasi, berdemo, dan demo. Kata yang berasal dari kata demo dipakai dalam wacana di atas. Setiap kalimatnya menjadi sebanding. Ketiga kata tersebut memiliki arti yang sama, yaitu melakukan protes atau ketidak setujuan terhadap suatu hal.

(14) Sekitar pukul 13.30 WIB, Pimpinan MPR hadir dan menunggu di Ruang Tunggu Utama Lantai Dasar. Berikutnya, sekitar pukul 13.40 WIB-14.10 WIB, kehadiran tamu kehormatan negara sahabat dan tamu undangan VVIP.

Wacana Data (14) di atas terdapat kata tunggu yang seapdan dengan kata menunggu. Kata yang memiliki dasar tunggu mengalami proses afiksasi me- dan menjadi menunggu. Kesepadanan ini dilakukan agar sesuai dengan kalimat sesudah dan sebelumnya.

(15) Belum jelas kasus yang menjerat pria bernama Ahmad Birawan ketika ditangkap menjelang pelantikan Presiden dan Wakil Presiden periode 2019-2024 hari ini. Agus, 26 tahun, menyaksikan penangkapan oleh polisi berjumlah sekitar 15 orang pada pukul o6.0o WIB. Sebagian polisi yang menangkap tampak menenteng senjata laras panjang.

Data (15) wacana diatas terdapat ekuvalensi pada kata penangkapan dan menangkap. Berasal dari kata dasar tangkap yang mengalami proses afiksasi pe-..-an, dan me- kata 
tangkap menjadi memiliki dua bentuk kata baru. Setiap kalimat haruslah memiliki kata yang sesuai denga kalimat-kalimat lainnya.

\section{Sinonimi}

Baryadi (2002: 27) mengatakan bahwa sinonimi adalah makna leksikal yang mirip antara kumpulan kata yang saru dengan kumpulan yang lain. Berikut ini dipaparkan beberapa wacana yang ditemukan leksikal sinonimi pada pemberitaaan pelantikan presiden oktober 2019 dalam media daring Tempo.co.

(16) Prabowo mengatakan dalam diskusi bersama Pimpinan MPR, dia juga menyampaikan jika perbedaan dalam berpendapat lumrah terjadi. Akan tetapi, semua untuk kepentingan bangsa. Dia juga menyampaikan dukungannya kepada MPR agar dapat bekerja memenuhi harapan rakyat dan tetap menjaga keharmonisan. Apalagi, menurut Prabowo, susunan Pimpinan MPR kali ini adalah yang terbaik.

Data (16) wacana sinonim yang terjadi pada mengatakan = menyampaikan dinamakan sinonim semirip. Dikatakan sinonim semirip karena makna dalam kedua kata itu adalah mengungkapkan, berbicara. Kemiripan bukan berasal dari katanya namun dari kedua makan tersebut. Makna yang memiliki kemiripan namun kata tidak mirip bisa dikatakan sinonim.

(17) Kepala Kepolisian RI Jenderal Tito Karnavian mengimbau masyarakat agar tak menggelar aksi demonstrasi atau unjuk rasa jelang dan saat pelantikan presiden dan wakil presiden terpilih.

Data (17) pada wacana di atasa ditemukan sinonim selingkung yaitu pada kata demonstrasi = unjuk rasa. Sinonim mutlak tersebut tidak mengubah makna, hanya berubah katanya saja. Namun jika kata tersebut dipakai secara terbalik atau misalkan kalimta kedua memakai kata pertama dan kalimat pertama memakai kata kedua, maka makna dan kalimat pun tidak akan berubah.

(18) Hal keempat yang Jokowi akan kerjakan adalah penyederhanaan birokrasi. Investasi untuk penciptaan lapangan kerja bakal diprioritaskan. "Prosedur yang panjang harus dipotong, birokrasi yang panjang harus kita pangkas," ucap Jokowi. Ia bahkan mengancam akan pecat menteri-menterinya nanti jika tidak serius menjamin tercapainya tujuan program pembangunan.

Data (18) pada penggalan kalimat "Prosedur yang panjang harus dipotong, birokrasi yang panjang harus kita pangkas" memiliki sinonim semirip. Potong = pangkas memiliki makna yang sama yaitu mengurangi atau membuat yang panjang menjadi lebih pendek.

(19) Dia juga mengucapkan apresiasi kepada KPU, Bawaslu, Kapolri, Mahkamah Konstitusi, institusi-institusi dan seluruh rakyat Indonesia yang telah menyukseskan pemilu. Selain itu, Bambang juga menyampaikan penghargaan atas pengabdian Wakil Presiden Jusuf Kalla mendampingi Presiden Joko Widodo sejak 2014-2019.

Data (19) pada wacana diatas didapatkan adanya sinonim mutlak yaitu, apresiasi = penghargaan. Kata apresiasi berarti memberikan penilaian berupa pujian, saran, atau pun komentar terhadap sesuatu, sedangkan kata penghargaan berarti memberikan suatu bentuk dari apresiasi. Kemutlakan ini tidak dapat dirubah bahwa apresiasi dapat berbupa apapun, yang berhubungan dengan penilaian. Pada wacana di atas, apresiasi yang diberikan berupa penghargaan.

(20) Emil pun mengimbau agar masyarakat Indonesia mendukung pemerintahan JokowiMa'ruf lima tahun mendatang. Terutama kepada masyarakat yang tidak memilih Jokowi, dia mengingatkan bahwa keduanya adalah pemimpin terpilih. "Kalau 
Fadila Sukma Wijaya

pemimpin udah dilantik, dan terpilih, mau dicoblos atau tidak, kita dukung. Beliau nakhoda hidup kita lima tahun," kata dia sebelum pelantikan presiden.

Data (20) pada sinonim pada wacana diatas aalah sinonim mutlak, pada penggalam wacana "Kalau pemimpin udah dilantik, dan terpilih, mau dicoblos atau tidak, kita dukung. Beliau nakhoda hidup kita lima tahun," Kata pemimpin = nakhoda yang maknanya sama nakhoda dalam artian seorang kepala atau pemimpin kapal laut. Kata pemimpin diibaratkan dengan nakhoda yang juga sama-sama memiliki kedudukan seorang pemimpin.

Antonimi

Leksikal antonimi bertolak belakang dari leksikal sinonimi, atau biasa disebutkan lawan kata. Leksikal antonimi adalah makna leksikal yang memiliki perbedaan dari segi makna. Maka konstituen yang satu dengan konstituen yang lainnya tidak sama atau bersifat berlawanan (Baryadi, 2002: 28). Ditemukan leksikal antonimi pada wacana pemberitaan pelantikan presiden oktober 2019 dalam media daring Tempo.co.

(21) Pramono menyebut Jokowi adalah orang yang paham tata negara. Sebabnya pelantikan tetap mengikuti jadwal yang sudah ditetapkan Komisi Pemilihan Umum (KPU). "Karena periodisasi DPR dan periodisasi itu sudah fix lima tahunan. Enggak boleh maju sehari, enggak boleh mundur sehari," ujarnya.

Data (21) pada wacana diatas ditemukan antonim kutub, pada wacana "Karena periodisasi DPR dan periodisasi itu sudah fix lima tahunan. Enggak boleh maju sehari, enggak boleh mundur sehari”. Antonim kutub yang terjadi karena adanya tingkatan antar makna maju $><$ mundur. Antonim ini juga mempertentangkan makna dimana pada wacana tidak diperbolehkan untuk dipercepat (maju) dan juga tidak boleh diperlambat (mundur).

(22) Maka dari itu, Tito pun mengimbau kepada masyarakat untuk tidak melakukan aksi, serta sekaligus mencegah ruang demonstrasi yang justru dimanfaatkan oleh oknum pelaku kericuhan."Pengalaman selama ini beberapa kali terjadi demo, waktu siang kan aman-aman saja, malamnya mulai lempar batu, merusak fasilitas umum," kataTito.

Pada data (22) penggalan wacana ."Pengalaman selama ini beberapa kali terjadi demo, waktu siang kan aman-aman saja, malamnya mulai lempar batu, merusak fasilitas umum," adanya antonim siang $><$ malam. Antonim ini adalah antonim mutlak. Karena kata siang dan malam adalah keadaan yang pasti terjadi dan tidak bisa dipertentangkan. Mutlak berarti hal yang harus ada atau memang adanya.

(23) Dengan banyaknya penangkapan in, Stanislaus meyakini, kelompok tersebut akan terurai dan semakin terdesak di luar Jakarta, sehingga mengubah model gerakannya. Dari kelompok besar, mereka bisa terdesak menjadi sel-sel kecil tingkat keluarga.

Data (23) pada penggalan wacana "dari kelompok besar, mereka bisa terdesak menjadi sel-sel kecil tingkat keluarga." adanya antonim hierarkial. Besar $><$ kecil memiliki makna yang berbeda karena makna yang memiliki tingkatan atau jenjang.

(24) Prabowo tak mengucapkan sepatah kata pun. Turun di lobi gedung Nusantara III, dia langsung berjalan menuju lift dan naik ke ruang pimpinan. Muzani, yang juga Wakil Ketua Majelis Permusyawaratan Rakyat, berkantor di lantai 7 gedung Nusantara III, sedangkan Dasco yang merupakan Wakil Ketua Dewan Perwakilan Rakyat berkantor di lantai 3 .

Data (24) wacana di atas“...Turun di lobi gedung Nusantara III, dia langsung berjalan menuju lift dan naik ke ruang pimpinan”. Penggalan wacana tersebut ditemukan antonim dalam kata turun $><$ naik. Kedua kata tersebut jelas bertolak belakang, antonim jenis 
inadalah antonim kutub. Karena memiliki perbedaan secara gradasi dan tingkatan antar makna.

(25) "Izinkan kami dari pimpinan meja majelis menyampaikan apresiasi setulus-tulusnya karena telah menerima hasil pemilu 2019 dengan jiwa yang besar. Ada saatnya kita bertempur dan ada saatnya kita bersatu kembali," ujarnya. Apresiasinya tidak hanya di situ, Bambang juga memuji kehadiran pasangan Prabowo dan Sandiaga melalui sebuah pantun.

Data (25) wacana diatas ditemukan antoinim pada satu kalimat "Ada saatnya kita bertempur dan ada saatnya kita bersatu kembali," ujarnya. Kata bertempur sangat bertolak belakang dengan kata bersatu (bertempur $><$ bersatu). Antonim ini adalah jenis antonim kutub. Bertempur berarti berkelahi atau berperang, sedangkan kata bersatu dalam wacana diartikan sebagai berdamai menjadi satu, memiliki tujuan yang sama.

Repetisi

Menurut Sumarlam (2010, 34) repetisi (pengulangan) adalah satuan lingual baik dalam bunyi, kata, atau kalimat yang diulang. Tujuannya adalah untuk memberikan keyakinan atau penekanan dalam sebuah konteks. Berikut adalah beberapa data yang ditemukan terkait repetisi.

(26) Bamsoet menyarankan, pejabat negara jangan kurangi kegiatannya. "Bahwa ada peristiwa itu, harus menjadi antisipasi oleh pihak keamanan. Namun para pejabat negara jangan kurangi kegiatan, harus tetap berdekatan dengan rakyat, urusan keamanan serahkan kepada pihak keamanan".

Data (26) wacana diatas menjadikan kata kemananan termasuk ke dalam repetisi penuh. Kata keamanan sering kali muncul pada setiap kalimatnya. Kata tidak ada penambahan atau pengurangan.

(27) Wali Kota Surakarta FX Hadi Rudyatmo mengatakan bahwa Wang Qishan sempat memuji keindahan Kota Solo. "Beliau bilang kalau Kota Solo sangat bersih," katanya. Menurut dia, Wang sempat menikmati pemandangan kota itu dari salah satu gedung berlantai 20.

Data (27) repetisi yang digunakan pada wacana di atasa adalah repetisi dengan penggantian. Pada nama orang Wang Oishan pada kalimat pertama, diulang kembali dan diganti dengan kata beliau pada kalimat tidak langsung. Lalu juga pengulangan pergantian terdapat pada nama Walikota Surakarta FX Hadi Rudyanto pada kalimat pertama, diulang kembali dengan kata yang diganti menjadi kata dia. Tujuannya dalam sebuah kalimat tidak lansung, memqng mebutuhkan kata pengganti orang.

(28) Pantauan Tempo, Presiden Joko Widodo atau Jokowi baru tiba di ruangan pelantikan sekitar pukul 15.28. Jokowi tiba beriringan dengan Wakil Presiden Jusuf Kalla. Di belakang Jokowi, tampak Wakil Presiden terpilih Ma'ruf Amin. setelah mereka masuk ke ruangan pelantikan, acara langsung dimulai. Pelantikan digelar di Gedung Kurakura MPR RI, Kompleks Parlemen, Senayan.

Data (28) pada repetisi yang terjadi pada kata Joko Widodo danPelantikan. Repetisi ini adalah repetisi dengan bentuk lain yaitu Joko Widodo yang diubah atau dipendekkan menjadi Jokowi dan repetisi penuh yaitu Pelantikan yang terdapat tiga kali pengulangan pada kata tersebut.

(29) Terlihat, puluhan aparat gabungan TNI-Polri sudah bersiaga di persimpanganpersimpangan jalan. Para tamu undangan pun saat masuk ke dalam harus menjalani pemeriksaan berlapis. Mereka harus menunjukkan identitas atau undangan mereka 
Fadila Sukma Wijaya

menghadiri pelantikan Jokowi - Ma'ruf. Pelantikan presiden akan dimulai pukul 13.00 WIB.

Data (29) di atas ditemukan kata persimpangan-persimpangan dan undangan. Kedua kata tersebut mengalami repetisi penuh. Repetisi ini, mengulang kata tampa adanya perubahan dari bentuk lain. Pengulangan terjadi untuk menekankan lagi suatu ujaran dalam wacana.

(30) Ketua MPR RI, Bambang Soesatyo atau yang biasa disapa Bamsoet, mengatakan bahwa kita perlu jaga persatuan dan kesatuan. Inilah pesan penting yang tersirat pasca pengumuman hasil kabinet Indonesia Maju. Pasti ada yang tidak puas, namun harus disambut baik.

Data (30) pada repetisi yang terjadi pada wacana diatas adalah mengulang nama orang. nama Panjang menjadi singkat Bambang Soesatyo atau yang biasa disapa Bamsoet. Repetisi ini bisa juga disebut dengan repetisi bentuk lain. Nama yang panjang dibuat menjadi singkat, tujuannya agar mudah untuk diingat dan tidak panjang dalam penyebutannya.

\section{Simpulan}

Dari hasil penelitian yang telah dibahas dapat disimpulkan bahwa, kohesi leksikal yang terdapat dalam pemberitaan pelantikan presiden pada media daring Tempo.co dari tanggal o1 hingga 26 Oktober 2019 terdapat 35 wacana, yang dikelompokkan menjadi beberapa jenis kohesi leksikal diantaranya, kolokasi 43, hiponimi 27, ekuivalensi (kesepadanan) sebanyak 33, sinonimi 49, antonimi 20, repetisi sebanyak 80. Penulis telah melakukan analisis dan data yang didapatkan banyak, namun penulis hanya menuliskan beberapa data yang sudah mendukung dari keseluruhan kohesi leksikal.

Dari data yang sudah dianalisis, kohesi leksikal dengan jenis repetisi banyak sekali ditemukan. Karena dalam wacana pemberitaan pelantikan presiden yang diunggah pada media daring tempo.co edisi Oktober 2019, terdapat banyak repetisi atau pengulangan dalam setiap paragrafnya. Pemakaian leksikal repetisi atau pengulangan pada setiap wacana biasanya dimaksudkan untuk, memberikan penegasan ulang atau meyakinkan kembali kepada pembaca. Selain menjadi penegasan, repetisi atau pengulangan juga dijadikan pengganti atau substitusi objek atau subjek yang dimaksud.

Penulis menyarankan pembaca untuk lebih mencari tahu lagi mengenai kohesi leksikal. Karena pemahaman mengenai kohesi sangat dibutuhkan dalam menganalisi suatu wacana. Penelitian ini diharapkan dapat bermanfaat dan menjadi bahan referensi penelitian selanjutnya untuk peneliti.

\section{Daftar Pustaka}

Almanar, AE. 2000. Kohesi Dalam Media Massa Cetak BahasaIndonesia.Jakarta: Pusat Bahasa Departemen Pendidikan Nasional

Arifin, Zaenal dkk. (2015). Wacana: Transaksional dan Interaksional dalam Bahasa Indonesia. Tangerang: Pustaka Mandiri

Baryadi, Praptomo. 2002. Dasar-Dasar Analisis Wacana dalam Ilmu Bahasa. Yogyakarta: Pustaka Gondho Suli

Hartono, Bambang. 2012. Dasar-Dasar Kajian Wacana. Semarang: Pustaka Zaman

Kushartanti, dkk. 2005. Pesona Bahasa: Langkah Awal Memahami Linguistik. Jakarta: Gramedia

Keraf, Gorys. 1980. Komposisi. Jakarta: Nusa Indah

Mulyana. 2005. Kajian Wacana. Yogyakarta: Tiara Wacana 
Nugrahani, Farida. 2010. Metodologi Penelitian Kualitatif: Teori dan Aplikasi. Surakarta: UNS Press

Sumarlam, dkk. 2010. Teori dan Praktik Analisis Wacana. Surakarta: Pustaka Cakra Surakarta

Tarigan, Henry Guntur. 2009. Pengajaran Gaya Bahasa. Bandung: Angkasa

Tonang, Ririn Hardianthy. 2018. Jurnal Bahasa dan Sastra: Kohesi Leksikal pada Surat Kabar Sulteng Raya. Vol 5 No. 2 (2020)

Utami, Iin Sri. 2016. Analisis Kohesi Leksikal Rubrik Pembaca Menulis Surat Kabar Tanjungpinang Pos edisi Februari 2016. Artikel E- Journal. Fakultas Keguruan dan Ilmu Pendidikan. Universitas Maritim Raja Ali Haji Tanjungpinang

Pernando, Erik \& Ade Rahima. 2017. Jurnal Aksara: Analisis Kohesi Leksikal dalam Majalah Patriotik LPM Universitas Batanghari edisi XVI Juli-September tahun 2016. Vol. 1 No. 1 September 2017

Tempo.co. 2019. https://www.tempo.co/ (diunduh pada tanggal 01- o6 Oktober 2019) 
